\title{
In Vitro Micrografting of Mature Carob Tree (Ceratonia siliqua L.)
}

\author{
Touria Hsina* and Noureddine El Mtili
}

Department of Biology, Laboratory of Biology and health, Faculty of Sciences, B.P. 2121 Tetouan, 93002 Morocco

\begin{abstract}
A micrografting technique was developed for Ceratonia Siliqua using in vitro germinated seedlings as rootstocks and apex or shoot cultures (established from mature female tree source) as microscions. In vitro germinated seedlings were decapitated and used as rootstock. Mature explants were initiated on Murashige and Skoog medium containing $30 \mathrm{~g} / \mathrm{l}$ sucrose, and $0.5 \mathrm{mg} / \mathrm{l} \mathrm{6-benzylaminopurine,} \mathrm{then} \mathrm{transferred} \mathrm{on} \mathrm{the} \mathrm{multiplication} \mathrm{medium} \mathrm{(Murashige} \mathrm{and} \mathrm{Skoog}+$ $0.5 \mathrm{mg} / \mathrm{l}$ 6-benzylaminopurine $+0.1 \mathrm{mg} / \mathrm{l}$ gibberellic acid $+0.1 \mathrm{mg} / \mathrm{l}$ indol-3- butyric acid). Micrografts could be easily cultured on the same medium and developed after one month. Grafting success has been dependent on the method of grafting. The micrografting on hypocotyl (central grafting) method was significantly more successful (92, 50\%) than the other grafts methods. The compatible graft union was observed one month after grafting. The histological cuttings showed that the graft union formation was initiated by the development of the callus bridge at the interface between scion and rootstock, after that, new vascular elements including vessels and tracheids were seen across the interface zone.
\end{abstract}

Key Words: Ceratonia siliqua, micrografting, female trees, in vitro culture.

\section{INTRODUCTION}

The carob tree (Ceratonia siliqua $\mathrm{L}$ ) is an important species environmentally and economically prevailing calcareous soils of the Mediterranean region. Traditionally, grafted carob trees have been interplanted with olives, grapes, almonds and barley in low-intensity farming systems in most producing countries. In some areas, such as in Mediterranean Turkey, south Spain and Morocco, pods from un grafted spontaneous trees are collected [1-3]. Carob trees may be male, female and hermaphrodite or polygamous inflorescences, showing high plasticity in inflorescences and flower characteristics $[4,5]$. Female plants always have been selected in preference to the hermaphrodite ones, as they are better pod bearers. The most common cultivars in commercial orchards are female, only a few hermaphrodite having sufficiently desirable attributes [6]. The female cultivars are the most important trees commercial groves of Mediterranean countries. Males and hermaphrodites are normally used as pollinators. Commercial world production of carob pods is estimated currently around $310000 \mathrm{t}$, and is mainly concentrated in Spain, Italy, Morocco and other countries. Carob production in Morocco has increased over the last 15 years and it is estimated to be about $26000 \mathrm{t}$ [7].

The global receipt due to carobs would reach 7, 94\% of plants-production value in the province of Chefchaouen (regions of northern Morocco) [8].

Traditional carob propagation has been achieved by grafting saplings with female buds chosen in productive trees (Battle and Tous 1997), this traditional carob propagation methods failed to meet the market request, the use of micro-

*Address correspondence to this author at the Department of Biology, Laboratory of Biology and health, Faculty of Sciences, B.P. 2121 Tetouan, 93002 Morocco; Tel: +21266687047; Fax: +21239994500;

E-mails: thsina@gmail.com and thsina@yahoo.fr propagation seems to be appropriate in order to fulfil the increasing demand for propagating this tree [9].

The micropropagation of the carob tree was realized by certain researchers [10-12]. In the traditional grafting, the optimal leaf development is observed in trees of grafted female aged from 10 to 20 years [13].

In vitro micrografting may provide several advantages such as elimination of viruses, rejuvenation of mature tissues, year round plant production, enhance compatibility studies and correlative relation between rootstocks and scions, breeding for specific genotypic combinations to increase plan productivity, and extention of ecological limits of a particular plant species or cultivar to tolerate edaphic conditions $[14,15]$

To optimize the production of carob, a right proposition between male and female plants is needed [16], with this objective; a micrografting of carob between seedling and explants from mature female tree was tested in our study.

\section{MATERIALS AND METHODS}

\section{In Vitro Seed Germination and Establishment Of Root- stock}

The seeds and explants were collected from the region of Chefchaoun (the North of Morocco). Mature seeds were softened by immersion in analytical sulphuric acid (95\%) for 20 min, and surface sterilized with $7 \%$ calcium hypochlorite solution by agitation for one hour with the addition of one or two drops of Tween- 80, or in $0.01 \%$ mercury chloride $\left(\mathrm{HgCl}_{2}\right)$ for $30 \mathrm{~min}$. After rinsing three times in sterile distilled water (SDW), the seeds were cultured in tubes containing DW solidified with $0.7 \%$ agar and autoclaved at 1 bar and $120{ }^{\circ} \mathrm{C}$ for $20 \mathrm{~min}$. The cultures were incubated in the light in a growth chamber $\left(25^{\circ} \mathrm{C}\right)$ for germination and the seedlings obtained were used as rootstock. 


\section{In Vitro Multiplication and Preparation of Microscion}

Juvenile shoots were harvested from the same adult female tree to surmount the genotypic effects. To obtain sterile scion, the shoots and cultured nodes and shoot tips were surface sterilized. The new growths from the sterile explants were used as source of scion in the experiments. Surface sterilization of explants was done using $0.1 \% \mathrm{HgCl}_{2}(6 \mathrm{~min})$, after rinsing three times in SDW, the basal end was trimmed and the shoot explants were cultured on solid MS [17] medium containing $3 \%$ sucrose, and $0.5 \mathrm{mg} / \mathrm{l} \mathrm{BA}$, and solidified with $0.7 \%$ Agar. After adjusting the $\mathrm{pH}$ to 5.8 the media was autoclaved at 1 bar and $120{ }^{\circ} \mathrm{C}$ for $20 \mathrm{~min}$. The ascorbic acid and citric acid $(100 \mathrm{mg} / \mathrm{l})$ were added to the medium as antibrowning solution. Shoot explants were established in this medium in tubes $(25 \mathrm{~mm} \times 150 \mathrm{~mm})$ at $25 \pm 2{ }^{\circ} \mathrm{C}$ under a $16 \mathrm{~h}$ photoperiod at an intensity of 60 micromol m $\mathrm{m}^{-2} \mathrm{~s}^{-1}$ provided by cool-white fluorescent light.

After four weeks, the explants were transferred onto the multiplication medium (MS + 0.5 mg/l BAP $+0.1 \mathrm{mg} / \mathrm{AG}_{3}$ $+0.1 \mathrm{mg} / \mathrm{l} \mathrm{AIB}$ ) and subcultured every month on the same medium to increase the production of new growths.

After 5 months, shoot multiplication was assessed by the shoot multiplication rate for the total number of shoots, and the mean length of the longest shoot produced per culture. Results presented are mean \pm standard error of 18 explants per subculture. All the experiments were carried out three times. Data were subjected to the analysis of variance (ANOVA) in order to assess treatment differences using the SPSS statistical package for Windows (release 12.0 SPSS INC.). Significant differences between means was tested by Tukey new multiple range test $(P=0.05)$.

\section{Methods of Grafting and Establishment of Micrografting}

Under aseptic conditions, shoots of uniform length and diameter were selected from in vitro cultures and used as scions in micrografting. In the first experiment, different methods of wedge grafts were tested to determine the micrografting optimum union. For the first method, the seedlings were decapitated $1.5 \mathrm{~cm}$ above the cotyledonary joint, a downward central incision of $0.5 \mathrm{~cm}$ was made and the wedge of microscion was inserted gently and firmly into the vertical split on the detopped seedlings. Similarly, in the two other methods, the rootstock seedlings were decapitated 0.5 $\mathrm{cm}$ below the cotyledons joint. A slanting incision at an angle of $45^{\circ}$ was made on the hypocotyl (for side grafting) and a downward central incision of $0.5 \mathrm{~cm}$ was also made on the hypocotyl (for central grafting) (Fig. 1).

The prepared cultures were inoculated on the MS medium containing $0.5 \mathrm{mg} / \mathrm{l} \mathrm{BAP}, 0.1 \mathrm{mg} / \mathrm{AG}_{3}, 0.1 \mathrm{mg} / \mathrm{l} \mathrm{AIB}$, $30 \mathrm{~g} / \mathrm{l}$ sucrose and $0.7 \%$ Agar. The $\mathrm{PH}$ of the medium was adjusted to 5.8 and autoclaved at 1 bar and $121{ }^{\circ} \mathrm{C}$ for 20 $\mathrm{min}$. The cultures were incubated for graft development in a growth chamber with the same conditions $\left(\right.$ at $25 \pm 2^{\circ} \mathrm{C}$ under a $16 \mathrm{~h}$ photoperiod at an intensity of 60 micromol m $\mathrm{m}^{-2} \mathrm{~s}^{-1}$ provided by cool-white fluorescent light). The success rate was determined one month after in vitro culture of graftings.

\section{Histology of Graft Development}

The sample graft combinations were harvested at two weeks and one month after grafting to study the sequence of anatomical events during the graft union formation. Section of 10 micrometers thick from longitudinal sections were cut and submerged in the Bleach for $10 \mathrm{~min}$, after rinsing in sterile water, the Sections were immerged in the acetic acid $(10 \%)$ for $5 \mathrm{~min}$, then in the solution of Carmino-vert for 15 min.

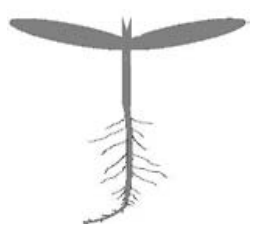

Rootstock

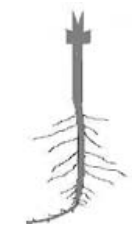

Rootstock

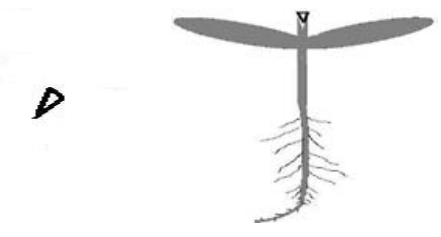

Scion
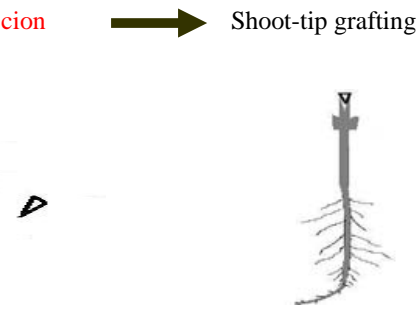

Scion

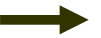

Shoot-tip grafting
Micrografting on epicotyle

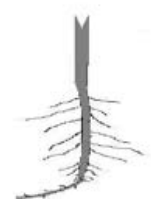

Rootstock

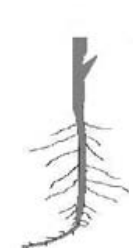

Rootstock

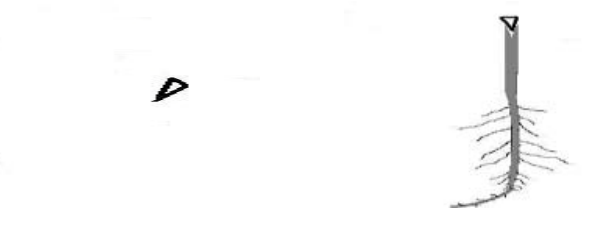

Scion

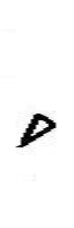

Scion
Central grafting

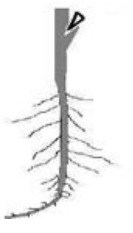

Side grafting
Micrografting on hypocotyle

Fig. (1). In vitro micrografting of Ceratonia siliqua with different methods of wedge grafts.

\section{RESULTS AND DISCUSSION}

\section{Multiplication of Microscion}

The multiplication technique of axillary buds was adopted to the majority of the ligneous species and obtaining sterile scions $[18,19]$.

The in vitro multiplication of adult female obtained more than $95 \%$ of the explants, and allowed to grow in order to have normal development (Fig. 2B).

Buds were developed on the MS establishment medium containing the BAP $(0.5 \mathrm{mg} / \mathrm{l})$ after 4 weeks of culture. The level of bud development was about $90 \%$ which is similar to that obtained by Romano et al. [9]. The multiplication stage 
gave a high number of bud production from explants (Table 1), shoots development was observed followed by callus formation in the base of explants, Numerous factors including nutritional, hormonal and physical conditions of the medium could be the cause of the defect in the formation of the young shoots [9]. However, Ruzie noticed that, the success of in vitro culture is strongly influenced by the chemical composition of the culture medium [20].

Table 1. Number of Shoots by Explants and their Mean Length During the Successive Subculture for Five Months

\begin{tabular}{|c|c|c|}
\hline Subculture & Mean Number of Shoots & Mean Shoot Length \\
\hline \hline 1 (January) & $1,39 \pm 0.11 \mathrm{~b}$ & $13,33 \pm 1.28 \mathrm{c}$ \\
\hline 2 (February) & $2,00 \pm 0.2 \mathrm{~b}$ & $20,33 \pm 1.19 \mathrm{~b}$ \\
\hline 3 (March) & $2,94 \pm 0.27 \mathrm{a}$ & $24,67 \pm 1.6 \mathrm{~b}$ \\
\hline 4 (April) & $3,22 \pm 0.25 \mathrm{a}$ & $34,11 \pm 1.03 \mathrm{a}$ \\
\hline 5 (May) & $3,11 \pm 0.22 \mathrm{a}$ & $34,06 \pm 1.32 \mathrm{a}$ \\
\hline
\end{tabular}

Values represent mean + standard error of three replicates with 18 explants per subculture. Values followed by the same letter are not significantly different at $P \leq 0.05$.

The successive subculture in the same multiplication medium significantly increased the number of shoots per explants as well as their mean length. The data in the Table $\mathbf{1}$ showed that there is a significant difference between both the first and the last subculture in the number of shoots per explants and their mean length. The increase of the number of shoots can be due to the physiological activity of shoots during the period of April and May.

\section{In Vitro Micrografting}

Grafting is an ancient technique which is commonly used in propagation of many species. For the ligneous plants, Franclet showed that the grafting of apex taken from explants cultivated in vitro is advantageous because it pulls a renovation of the mature material [21]. The rootstock was easily obtained two weeks after in vitro seed germination (Fig. 2A).

The success rate of in vitro grafting of Ceratonia siliqua varied according to the type of grafting. The micrografting on hypocotyl (central grafting method) was significantly more successful $(92,50 \%)$ than the other grafts methods (Table 2) according to the Tukey test $(\mathrm{P} \leq 0.05)$, the growth of scion is rapid in central grafting method after 4 weeks of culture. In central grafting, no problems were observed during the union formation as long as the contact surfaces were perfectly smooth. On the other hand, the side grafting and the micrografting on epicotyl (with cotyledons) were more difficult to perform and had lower success rate. The reestablishment of growth by scions was evident one month after grafting (Fig. 2C).

Development of new shoots from axillary buds in the rootstock (Fig. 2D) was observed in all central micrografts. These results agreed with the results obtained by Thimmappaih [22] who concluded that by micrografting axillary buds from mature tree source, elongation of shoots was observed.
Table 2. Number of Grafts and Grafting Success According to Method of Grafting

\begin{tabular}{|c|c|c|}
\hline Method of Grafting & $\begin{array}{c}\text { Number } \\
\text { of Grafts }\end{array}$ & $\begin{array}{c}\text { Grafting } \\
\text { Success (\%) }\end{array}$ \\
\hline \hline $\begin{array}{c}\text { Micrografting on epicotyl } \\
\text { (with cotyledons) }\end{array}$ & 24 & $10 \mathrm{a}$ \\
\hline $\begin{array}{c}\text { Micrografting on epicotyl } \\
\text { (without cotyledons) }\end{array}$ & 24 & $51,66 \mathrm{~b}$ \\
\hline $\begin{array}{c}\text { Micrografting on hypocotyl } \\
\text { (Central grafting) }\end{array}$ & 24 & $16.66 \mathrm{c}$ \\
\hline $\begin{array}{c}\text { Micrografting on hypocotyl } \\
\text { (Side grafting) }\end{array}$ & 24 \\
\hline
\end{tabular}

Values represent mean \pm standard error of three replicates with 24 grafts. Values followed by the same letter are not significantly different at $P \leq 0.05$.
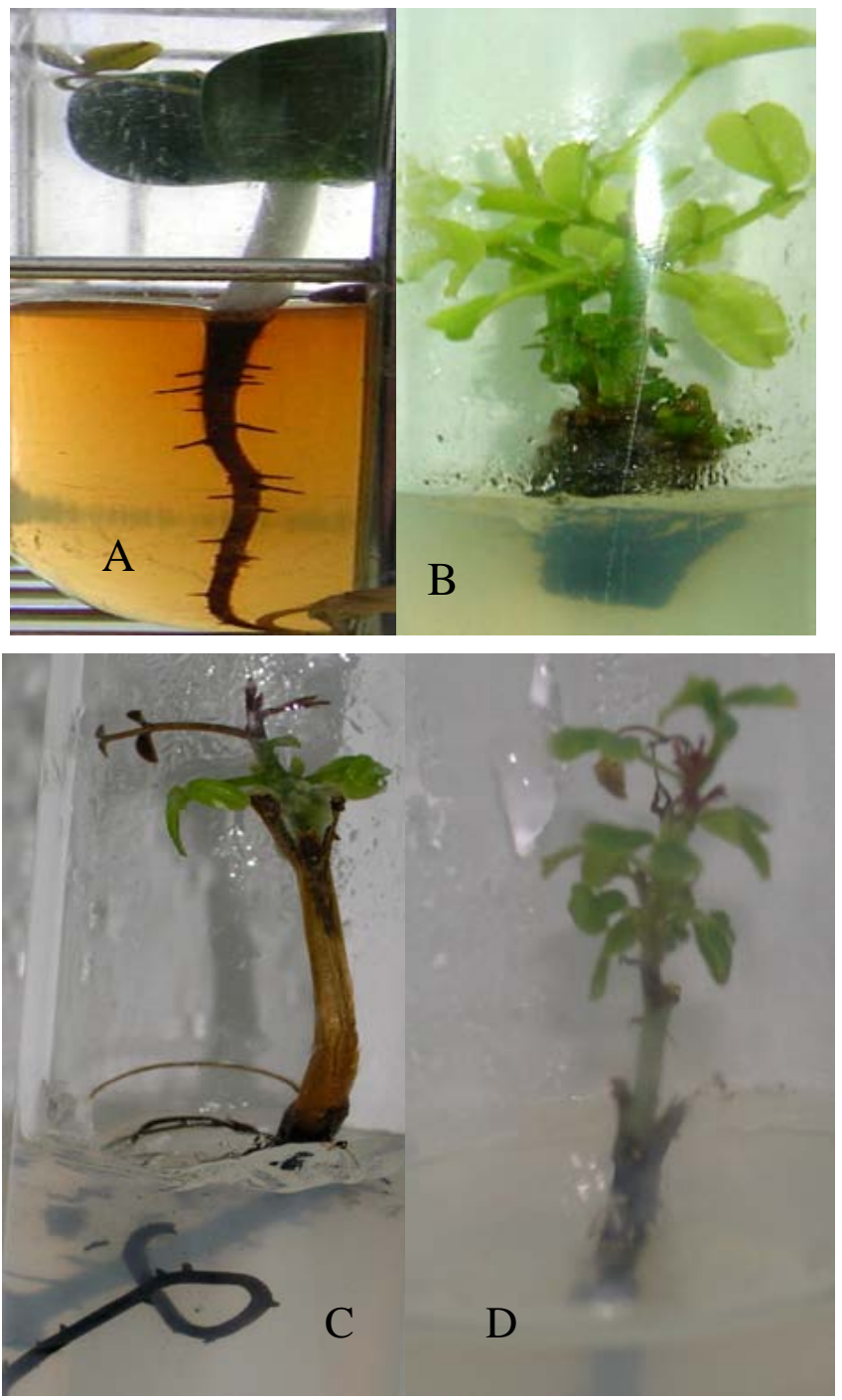

Fig. (2). (A) Seedling (two weeks old) germinated in the water with Agar. (B) Shoot-culture at the end of multiplication stage in MS medium containing $0.5 \mathrm{mg} / \mathrm{l} \mathrm{BAP,} 0.1 \mathrm{mg} / 1 \mathrm{AG}_{3}$ and $0.1 \mathrm{mg} / \mathrm{l} \mathrm{AIB}$. (C) Micrograft established in the same multiplication medium, development of the scion 4 weeks after micrografting. (D) Micrograft development after four months. 
Also, the development of scion on the rootstock showed that the MS medium with $3 \%$ sucrose, $0.5 \mathrm{mg} / \mathrm{l} \mathrm{BAP,} 0.1$ $\mathrm{mg} / \mathrm{l} \mathrm{AG}_{3}$ and $0.1 \mathrm{mg} / \mathrm{l}$ AIB used was favourable to micrografting culture.

The reason for the higher level of development of scion observed in homograft may have happened because the plants are more closely related, more physiologically compatible and have effect on increased rate of regeneration of the micrograft.

\section{Anatomy of the Graft Union Formation}

The histological examination made on micrograft allows showing at the level of grafting, the degree of compatibility between both partners (rootstock and scion) [23].

Evidence of the compatibility between rootstock and scion during micrografting is the high percentage of success of grafting, and the establishment of the vascular tissue continuity observed in the histological study [24]. This agrees with the results obtained in our study.

Moore 1984 [25] and Hartmann et al., [15] have described four general steps during a compatible graft union formation: formation of the union, development of a necrotic layer and proliferation of callus bridge at the graft interface, differentiation of new vascular and restoration of the continuity of new vascular tissue. After two weeks of micrografting, the histological cuttings demonstrated the initiation of graft union by the development of callus bridge at the interface between scion and rootstock, and this happened by a cell division from tissue of both partners grafts (Fig. 3a, b). Then, the callus filled all spaces on the interface. After several days, cell differentiation initiated on parenchyma cells in both stock and scion tissues, which were located close to the disrupted vascular tissues. The originated cells were elongated and oriented towards the callus bridge (Fig. 3a, b). The functional and compatible graft union was observed one month after grafting and in vitro culture when the scion began a vigorous growth, new vascular elements including vessels and tracheids were seen to unite across the interface zone (Fig. 3c, d). The histological observation showed more numerous and wider zones of proliferation. The vascular tissues pulls in touch with cambium tissues offering the possibility of a connection with vascular tissues for micrografting of peach tree [26]. A quick contact is established between both partners and the activity of respective vascular tissues contributing to the formation of a continuous connection between the scion and the rootstock. This is a case of compatibility between both partners.

\section{CONCLUSION}

The micropropagation of the carob tree was successfully obtained in sterile scions. A micrografting technique using in vitro cultured seedlings as rootstock and shoots scion from a mature tree female was successful in Ceratonia siliqua.

The evidence of compatible graft union formation is proliferation of callus bridge at the interface, differentiation of new vascular cambium and restoration of the continuity of new vascular tissues.

The technique of micrografting allows to improve the conditions of traditional grafting and the obtaining of the strong grafts.

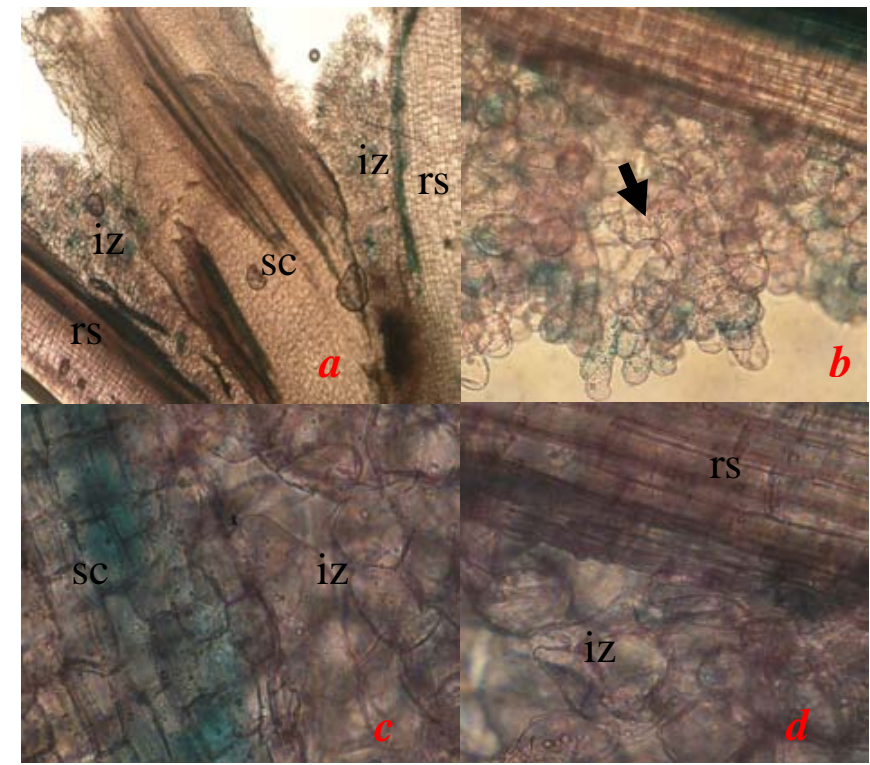

Fig. (3). Longitudinal section of micrograft between seedling (rootstock) and culture established from mature female tree source (scion). (a) Micrografting showing interface zone (iz) between rootstock (rs) and scion (sc) [4X]. (b) Two week old micrografting showing the proliferation of Callus Bridge cells [40X]. (c and d) one month old micrografting showing elongated cells in process of differentiation to regenerate vascular tissues [100X].

\section{ABBREVIATIONS}

$$
\begin{aligned}
& \text { MS }=\text { Murashige and Skoog } \\
& \mathrm{BAP}=6 \text {-benzylaminopurine } \\
& \mathrm{AG}_{3}=\text { Gibberellic acid } \\
& \mathrm{AIB}=\text { Indol-3- butyric acid }
\end{aligned}
$$

\section{REFERENCES}

[1] Vardar Y, Seçmen O, Oztürk M. Some distributional problems and biological characteristics of ceratonia in Turkey. Portug Acta Biol 1980; (A) XVI(1-4): 75-86.

[2] Ouchkif M. Etude sur le caroubier. Append number 8 of Project Oued Serou. MARA (Morocco)-GTZ, DPA of Khenifra, Germany 1988.

[3] Battle I, Tous I. Carob tree. Ceratonia siliqua L. Promoting the conservation and of under-utilised and neglected crops, 17 (93P). Institute of Plant Genetics and Crops Plant Research. Gatersleben / International. Plant Genetic resources institute. Rome, Italy 1997.

[4] Haselberg C Von. A contribution to the classification and characterisation of female and male varieties of Ceratonia siliqua L. In: Fito P, Mulet A, Eds. Proceedings of the II International Carob Symposium. Valencia: Spain 1988; pp. 137-51.

[5] Tucker SC. The developmental basis for sexual expression in ceratonia siliqua (Luguminosae: Caesalpinioideae). Am J Bot 1992; 79(3): 318-27.

[6] Tous J, Romero A, Plana J, Battle I. Current situation of Carob plant material. In Proceedings of the III International Carob symposium 1996; Cabanas-Tavira, Portugal (In press).

[7] Batlle I. Current situation and possibilities of development of the carob tree (Ceratonia siliqua L.) in the Mediterranean region. Unpublished FAO Report; Rome, Italy 1997.

[8] Gharnit N, Elmtili N, Ennabili A, Sayah F. Importance socioeconomique du caroubier (Ceratonia siliqua L.); dans la provaince de Chefchaouen (nord-ouest du Maroc) 2006.

[9] Romano H, Barros S, Martins-Louçao M. Micropropagation of the Mediterranean tree Ceratonia Siliqua L. Plant Cell Tissue Organ Cult 2002; 68: 35-41. 
[10] Sebastian KT, McComb JA. A micropropagation system for carob (Ceratonia siliqua L.). Sci Hortic 1986; 28: 127-31.

[11] Haselberg C. Flowering characteristics of male and female carob flowers. 1. Encontro Linhas de Invistigação de Alfarroba. Oeiras 1986; 45-56.

[12] Belaizi M, Bolen MR, Boxus P. Régénération in vitro et acclimatation du caroubier (Ceratonia siliqua L.), Ed. AUPELF-UREF. John Libbey Eurotext, Paris 1994; pp. 227-32.

[13] Custódio L, Carneiro MF, Romano A. Microsporogenesis and anther culture in carob tree (Ceratonia siliqua L.). Sci Hortic 2005; 104: 65-77.

[14] Richardson FVM, Mac An tSaoir S, Harvey BMR. A study of the graft union in in vitro micrografted apple. Plant Growth Regul 1996; 20: 17-23.

[15] Hartmann HT, Kester DE, Daveis FT Jr, Geneve RL. Plant propagation-Principales and Practices, $6^{\text {th }}$ ed. Pentice-hall: Englewood Cliffs, NJ 1997.

[16] Carimi F, Dilorenzo R, Crescimanno FG. Callus induction and somatic embryogenesis in carob (Cer. S L.) from ovule culture. Sci Hortic 1997; 70: 73-9.

[17] Murashig T, Skoog F. A revised medium for rapid growth and bioassays with tobacco tissue culture. Physiol Plant 1962; 15: 47397.

[18] Snir I. In vitro propagation of sweet cherry Cultures. Hortic Sci 1982; 17: 192-3.
[19] Deogratias JM, Lutz A, Dosba F. Micropropagation d'apex de cerisiers (Prunus avium L) multipliés in vitro en vue de l'élimination de trois types de particules virales (CLSV, PDV, et NRSV). Fruits 1986; 41(11): 675-80.

[20] Ruzié D, Cerovié SR, Culafié Lj. Contents of macronutrients and growth of Sweet Cherry rootstock in vitro. Biol Plant 2004; 47 463-5.

[21] Franclet A. Rajeunissement et micropropagation des ligneux, Proc Coll Int Cult in vitro. Essences Forestière 1U FRO. Fontainebleau France, AFOCEL 1981; pp. 55-64.

[22] Thimmappaiah GT, Shirly P, Anil R. In vitro grafting of Cashew (Anacardium occidentale L.) Sci Hortic 2002; 92: 177-82.

[23] Abdelhamid S. Microgreffage in vitro du châtaignier. Revue suisse Vitic. Arboric Hortic 2004; 36(2): 87-92.

[24] Estarda-luna AA, López-Peralta C, Cárdenas-Soriano E. In vitro micrografting and the histology of graft union formation of selected species of prickly pear cactus (Opuntia spp.). Sci Hortic 2002; 92: 317-27.

[25] Moore R. A model for graft compatibility-incompatibility in higher Plants. Am J Bot 1984; 7(5): 752-8.

[26] Errea P, Felipe A, Herrero M. Graft establishment between compatible and incompatible Prunus spp. Unidad de Fruticultura, SIADGA, Campus de Aula Dei Apdo. 727, 50080 Zaragoza, Spain. J Exp Bot 1994; 45: 393-401.

(c) Hsina and El Mtili; Licensee Bentham Open.

This is an open access article licensed under the terms of the Creative Commons Attribution Non-Commercial License (http://creativecommons.org/licenses/ by-nc/3.0/) which permits unrestricted, non-commercial use, distribution and reproduction in any medium, provided the work is properly cited. 